\title{
Pelaksanaan Training Dalam Meningkatkan Kinerja Karyawan
}

\author{
Khaeruman $^{\text {a }}$, Gatot Hartoko ${ }^{\text {b }}$ \\ ${ }^{a}$ Universitas Bina Bangsa, khaeruman.oce@gmail.com \\ aUniversitas Bina Bangsa, gatot.hartoko@yahoo.co.id
}

\begin{abstract}
A b s t r a k
Sumber daya manusia merupakan sumber daya yang paling menentukan keberhasilan suatu organisasi. Outbound training adalah kegiatan simulasi atau pelatihan yang dilakukan di lapangan terbuka, cocok untuk banyak perusahaan. Pelatihan semacam ini sangat efektif dalam meningkatkan semangat kerja karyawan. Penelitian ini bertujuan untuk mengetahui bagaimana pelaksanaan pelatihan untuk meningkatkan kinerja karyawan CV. XYZ. Penelitian ini menggunakan penelitian kualitatif dan metode deskriptif. Dalam teknik pengumpulan data, hasil data diperoleh dari observasi, pencatatan dan wawancara. Menafsirkan hasil wawancara untuk menjelaskan hasil penelitian, dan mengajukan pertanyaan kepada karyawan dalam bentuk pertanyaan. Menurut hasil penelitian, pelatihan yang diterapkan perusahaan berada di luar pelatihan perusahaan (off-job training). Metode yang digunakan adalah metode (experiential learning) atau proses belajar melalui pengalaman. Melalui pengalaman belajar, kerja tim yang solid akan terbentuk. Pelaksanaan pelatihan pegawai ini telah merangsang semangat pegawai untuk melakukan pekerjaan dengan baik. Menjadikan kinerja pegawai dilihat dari kemampuan, tingkat pengetahuan, semangat kerja dan kelancaran kerja.
\end{abstract}

Kata Kunci: Sumber Daya Manusia, Training, Kinerja, Organisasi.

\section{A b s tract}

Human resources are the resources that most determine the success of an organization. Outbound training is a simulation or activity carried out in an open field, suitable for many companies. This kind of training is very effective in increasing employee morale. This study aims to determine how training implementation improves employee performance $C V$. XYZ. This study uses qualitative research and descriptive methods. In data collection techniques, the data results are obtained from observation, recording, and interviews. They were interpreting interview results to explain research results and asking employees questions in the form of questions. According to the research results, the training implemented by the company is outside the company's training (offjob training). The method used is the method (experiential learning) or the learning process through experience. Through learning experiences, solid teamwork will be formed. The implementation of this employee training has stimulated the enthusiasm of employees to do a good job. They are making employee performance seen from the ability, level of knowledge, morale, and smooth work.

Keywords: Human Resources, Training, Performance, Organization.

\section{Pendahuluan}

Sumber Daya Manusia (SDM) adalah sumber daya terbanyak menentukan keberhasilan suatu organisasi. Organisasi harus memiliki nilai lebih dari organisasi lain. Di era globalisasi saat ini, ditandai dengan perubahan cepat seperti itu, organisasi atau institusi harus melakukan penyesuaian dalam semua aspek organisasi. Dengan keterbatasan sumber daya manusia yang ada, organisasi berharap dapat mengoptimalkannya untuk mencapai tujuan organisasi yang telah ditetapkan (Handoko, 2014). 
Penggunaan sumber daya penting ini membutuhkan manajemen atau kemampuan teknis perusahaan untuk membuatnya sangat berguna dan bermanfaat. Pengembangan sumber daya manusia merupakan rencana utama efektivitas perusahaan, karena terwujudnya tingkat efisiensi dan daya saing tergantung pada kualitas rencana sumber daya manusia tersebut. Seperti yang diungkapkan Mangkuprawira (2004:151), karyawan tertinggal dalam hal pengetahuan dan keterampilan. Keragaman karyawan domestik dan internasional, perubahan teknologi dan pergantian karyawan merupakan tantangan yang dihadapi perusahaan. Oleh karena itu, diperlukan sumber daya manusia yang berkualitas karena sumber daya manusia Departemen di sini dapat mempertahankan karyawan yang efektif melalui perencanaan sumber daya manusia. Oleh karena itu, jika perusahaan tidak memanfaatkan peluang dan tantangan yang muncul, maka tidak akan tercapai pola kerja yang baik dan lingkungan perusahaan yang kondusif. Dalam suatu perusahaan, tidak hanya karyawan yang dapat dengan cekatan menguasai tugas-tugas organisasi, tetapi yang lebih penting adalah tugas-tugas pribadi di lingkungan kerja. Sumber daya manusia yang berkualitas merupakan syarat perusahaan untuk mencapai tujuan yang diharapkan.

Penerapan pelatihan mengharuskan karyawan untuk berperilaku dan menyesuaikan diri dalam suatu komunitas. Mereka harus saling membantu untuk bekerja sama untuk menyelesaikan masalah yang dihadapi dengan tidak mempertimbangkan posisi dan peringkat antara yang lain. Pelatihan Outbound adalah peluang belajar aktif, yang berarti bahwa situasi pembelajaran aktif (bukan pasif) melibatkan semangat, tubuh, jiwa individu dalam upaya penemuan (untuk bertemu) dengan tantangan yang melibatkan intelektual, emisi, sosial, sosial, sosial, sosial, Arah fisik dan spiritual yang berarti bahwa itu adalah upaya untuk memenuhi kebutuhan Anda dan peka terhadap lingkungan sekitarnya.

Penerapan pelatihan juga dapat menciptakan kondisi kerja yang baik. Tetapi manusia ingin bekerja adalah karena keinginan atau pengemudi yang timbul darinya. Pengemudi lain tidak hanya dalam bentuk ekonomi, tetapi mereka juga ingin komentar dalam bentuk sosial, yaitu penilaian, kekaguman rekan dan kepuasan yang dapat beralih dari dalam dirinya. Untuk muncul pekerjaan yang baik di tempat kerja, perusahaan harus dapat memenuhi kebutuhan dan keinginan mengemudi karyawan atau pekerja. Menurut Schuler (1997: 345), mengatakan pelatihan karyawan mencakup dua kursus, yaitu pada pelatihan kejuruan (pelatihan tempat kerja) dan keluar dari pelatihan kejuruan. Tetapi pelatihan yang digunakan adalah pelatihan di luar tempat kerja berdasarkan metode (experiential), yaitu pengalaman pendekatan pembelajaran. Berkat proses pembelajaran dengan pengalaman ini, dapat digunakan sebagai pengembangan diri untuk karyawan di masa depan. Dan juga menguntungkan banyak perusahaan karena dapat meningkatkan kualitas pemikiran karyawan untuk menganalisis masalah dalam masyarakat.

Dapat disimpulkan bahwa tujuan yang dilakukan oleh Outbound Training dan hasrat kerja yang kuat dari karyawan meningkatkan kapasitas setiap karyawan atau individu dalam realisasi kelembutan dan kemajuan perusahaan. Diharapkan bahwa karyawan yang mengambil program pengembangan ini dapat lebih sensitif terhadap perubahan dalam masyarakat dan berpartisipasi aktif dalam upaya pelatihan iklim yang 
lebih baik. Bagi karyawan untuk menghasilkan karyawan menghasilkan kinerja yang lebih baik bagi perusahaan melalui implementasi Outbound Training itu.

Kinerja karyawan tergantung pada hasil pekerjaan atau kegiatan yang ada dalam organisasi yang dipengaruhi oleh faktor internal dan eksternal. Sebagai akun utama, sumber daya manusia (SDM) organisasi harus ditingkatkan dengan produktivitas dengan menciptakan kondisi kerja dan lingkungan yang dapat mendorong karyawan untuk meningkatkan disiplin kerja, benda kerja dan pekerjaan. Motivasi dengan cara yang optimal sehingga dapat meningkatkan karir. pengembangan untuk mendukung kinerja.

CV. XYZ adalah perusahaan yang berada di bawah bayang-bayang pemerintah, di mana perusahaan tersebut dikenali oleh pemasaran legalitas, kualitas produk sehat dan higienis dan mencatat dan memiliki banyak cabang di beberapa kota di Indonesia. Oleh karena itu, perusahaan ini memiliki perspektif jangka panjang yang sangat baik.

Dengan lingkungan yang strategis, akan ada lingkungan masyarakat yang kondusif. Perusahaan ini menjanjikan kemajuan dalam bisnis dan terbukti di beberapa kota di Indonesia. Dengan meningkatnya perkembangan masyarakat ini, banyak di antaranya ingin meniru kesuksesan mereka, semakin banyak perusahaan yang telah ditemani dan secara tidak langsung menjadi pesaing ini sehingga pendapatan telah menurun. Selain itu, karya yang semakin "lesu" karyawan yang disebabkan oleh banyak faktor.

Beberapa faktor yang menjadi penyebab karyawan kurang antusias pada pekerjaan "lesu", yaitu waktu kerja karyawan yang solid, ada kebosanan saat bekerja karena pekerjaan saturasi, lingkungan kerja yang buruk atau suasana. Pekerjaan yang tidak menyenangkan membuat karyawan tidak bersemangat di bekerja. Dengan demikian, bagaimana manajemen masyarakat menjawab semua ini. Pada awal-awal, direktur perusahaan menyelenggarakan pelatihan (outbound) untuk staf, ternyata hasilnya cukup memuaskan, yang kemudian ditransfer dengan mengadakan pintu keluar keluar untuk semua karyawan untuk memperkuat etika kerja dan Kinerja karyawan yang telah mengalami pembalikan dan hasil hingga hari ini dilihat oleh etika yang semakin padat dan etika dan pertunjukan karyawan yang menunjukkan lebih banyak kemajuan.

Awal dari pintu outbound perusahaan adalah pada tahun 2020. Pada awalnya, hanya untuk lingkaran sendiri (internal) yang dikembangkan kemudian untuk umum (eksternal), yang saat ini memiliki tempat keluar permanen di udara terbuka, seperti Karakar dan Selorejo bendungan. Ini membuktikan bahwa pelatihan outbound Training dapat digunakan sebagai alat sebagai cara untuk meningkatkan pekerjaan karyawan.

Perumusan masalah dalam penelitian ini adalah sebagai berikut:

a. Metode apa yang diterapkan perusahaan dalam melakukan training bagi karyawan?

b. Bagaimana kinerja karyawan sebagai dampak dari pelaksanaan training pada perusahaan CV. XYZ?

\section{Landasan Teori}

\subsection{Pengembangan Sumber Daya Manusia}

Kinerja adalah aspek penting dari upaya untuk mencapai tujuan atau lembaga perusahaan. Dengan kinerja karyawan yang baik di perusahaan atau agensi, Perusahaan atau badan tersebut akan dapat mencapai tujuan yang mereka inginkan. Hal ini disebabkan oleh 
kinerja sebagai penentu keberhasilan dan kelangsungan hidup masyarakat. Di setiap organisasi, manusia adalah salah satu elemen penting dari kebangkitan organisasi.

Kinerja adalah istilah yang populer di dalam manajemen, yang mana istilah kinerja didefinisikan dengan istilah hasil kerja, prestasi kerja dan performance (Martoyo, 2010:3). Kinerja merupakan aspek penting dalam upaya pencapaian tujuan perusahaan atau instansi. Dengan kinerja pegawai/karyawan yang baik pada suatu perusahaan atau instansi, maka perusahaan atau instansi tersebut akan dapat mencapai tujuan yang diinginkannya. Menurut Mangkunegara pengertian kinerja merupakan istilah yang berasal dari kata job Permomance. Kinerja dosen merupakan salah satu faktor penentu keberhasilan proses belajar mengajar di perdosenan tinggi. (Mangkunegara, 2017:9).

Dalam pengertian lain yang berarti, itu adalah hasil dari pekerjaan yang dicapai oleh seseorang berdasarkan persyaratan kerja. Pekerjaan memiliki persyaratan tertentu untuk mencapai tujuan kerja atau standar tenaga kerja. Untuk kinerja yang dihasilkan dari kualitas kerja dan jumlah yang diperoleh oleh karyawan dalam menjalankan tugasnya sesuai dengan tanggung jawab yang diberikan kepadanya.

\subsection{Penilaian Kinerja}

Penilaian Kinerja adalah upaya untuk menentukan secara berkala bagaimana efektivitas operasional pendukung organisasi dan pribadi dengan nilai-nilai signifikan, yaitu penentuan kontribusi masing-masing pembicara pribadi yang diungkapkan oleh penyelesaian tugas dan tanggung jawab (Umar, 2013). Ruky (2006:14) mengungkapkan bahwa istilah kinerja sebenarnya merupakan pengalihbahasaan dari kata Inggris yaitu performance.

Untuk lebih banyak peneliti yang menyarankan bahwa makna evaluasi kinerja adalah 1) mengalami tingkat pencapaian tujuan organisasi, 2) menyediakan fasilitas pembelajaran karyawan, 3) peningkatan kinerja berikutnya, 4) memberikan pertimbangan sistematis dalam pengambilan keputusan dan hukuman, 5) Memotivasi karyawan, 6) menciptakan akuntabilitas publik.

\subsection{Faktor-Faktor yang Mempengaruhi Pelatihan dan Pengembangan dalam Pencapaian Kinerja}

Faktor-faktor yang memiliki pengaruh langsung pada tingkat kinerja menurut Ruky (2006: 124), faktor-faktor mempengaruhi pelatihan dan pengembangan dalam pencapaian kinerja sebagai berikut:

a. Teknologi yang terdiri dari peralatan kerja dan metode kerja yang digunakan untuk menghasilkan produk atau layanan yang diproduksi oleh organisasi.

b. Kualitas masuk atau peralatan yang digunakan oleh organisasi.

c. Kualitas lingkungan fisik termasuk keselamatan kerja, penataan ruangan dan kebersihan.

d. Budaya organisasi sebagai model perilaku dan pekerjaan kerja dalam organisasi yang bersangkutan.

e. Kepemimpinan sebagai upaya untuk mengendalikan anggota organisasi untuk bekerja sesuai dengan standar dan tujuan organisasi

f. Manajemen Sumber Daya Manusia yang mencakup aspek kompensasi, promosi dan lainnya.

\section{Metode}

Metode ini adalah cara untuk mencapai tujuan dari definisi metode penelitian menurut Sugiyono (2017) bahwa "metode penelitian ditafsirkan sebagai cara ilmiah untuk 
memperoleh data yang valid dalam tujuan, membuktikan dan mengembangkan kenalan. Jadi bisa dikonfrontasi. Metode penelitian akan memerlukan peneliti tentang urutan bagaimana penelitian dilakukan dan merupakan pedoman dalam hal pengumpulan dan penelitian data. Adapun komponen-komponen metode kualitatif adalah sebagai berikut:

\subsection{Lokasi dan Subyek Penelitian}

Lokasi yang dipilih untuk melakukan pencarian ini adalah CV. XYZ. Perusahaan ini adalah organisasi yang memang kondusif untuk membuka pelatihan. CV. Ini adalah organisasi yang memiliki perspektif yang sangat baik di masa depan. Perusahaan perlu untuk bergerak maju dan berkembang dengan munculnya pesaing lain. Sumber Daya Manusia yang ada harus secara otomatis menyesuaikan diri dengan upaya untuk meningkatkan kinerja dan keterlibatan kinerja. Subjek penelitian digunakan untuk menentukan pencarian yang lancar sehingga tahap penelitian lebih diarahkan. Subjek penelitian ini adalah pemimpin atau manajer dan karyawan CV. XYZ dalam melaksanakan kegiatan Outbound Training yang diterapkan dalam perusahaan tersebut.

\subsection{Jenis Penelitian dan Sumber Data}

Penelitian ini dilakukan dengan menggunakan jenis penelitian tentang pendekatan deskriptif kualitatif. Dalam penelitian ini tidak menggunakan atau tidak menguji hipotesis. Penelitian mengembangkan konsep dan menghimpun data, tetapi tidak melakukan pengujian hipotesa. Untuk dapat menganalisis dan menafsirkan data yang baik, data yang dikumpulkan harus relevan dengan masalah tersebut. Dalam penelitian ini, penulis mendapatkan data diperlukan menggunakan sumber data primer (data utama) dan sumber data sekunder (data tambahan).

\subsection{Teknik Pengumpulan Data}

Penelitian ini adalah perusahaan pengumpulan bisnis yang secara langsung mengunjungi lokasi penelitian dan observasi dan kondisi yang terjadi. Beberapa teknik pengumpulan data yang dapat digunakan dalam penelitian ini diantaranya: (1) Pengamatan atau observasi, (2) Dokumentasi, (3) Wawancara atau interview.

\section{Hasil analisis dan Pembahasan}

\subsection{Hasil Analisis}

\subsubsection{Budaya Kerja CV. XYZ}

Untuk menciptakan suasana kerja yang nyaman dan kerjasama yang baik dari antar anggota CV. XYZ buat budaya kerja untuk setiap anggota yaitu:

a. Membangun rasa gotong royong (saling membantu).

b. Kerja sama antara anggota untuk membuat rasa persahabatan sehingga kerja tim dilatih.

c. Memprioritaskan pelanggan d. Inovasi.

d. Tingkatkan persaingan dari sumber daya manusia.

e. Bentuk karyawan untuk lebih memprioritaskan ibadah dan meningkatkan iman terhadap Tuhan sehingga ada jiwa yang bersih

\subsubsection{Waktu Pelaksanaan Outbound Training}

Pelaksanaan outbound training ini diadakan setiap bulan. Durasi waktu pelatihan pada dasarnya diadaptasi dengan keinginan pelanggan atau peserta dalam pelatihan, tetapi untuk hasil yang optimal, program pelatihan ini membutuhkan waktu yang efektif (3 hari/2 malam) atau kombinasi dengan seperangkat set tur satu Pelatihan hari mungkin 
merupakan tur Segtseing yang dipersonalisasi dengan keinginan pelanggan atau peserta pelatihan. Dan hasil pengamatan mengenai lokasi yang dipilih untuk kegiatan Outbound Training, yaitu pilihan lokasi yang mendukung sisi psikologis peserta untuk merasakan suasana alami bebas yang menginspirasi antusiasme, tantangan, bebas dan segar, dan jauh dari keramaian dan agitasi kota serta polusi udara. Tetapi jika Anda tidak dapat melakukan kegiatan pada medan terbuka, kegiatan Outbound Training dapat dilakukan di lapangan, halaman kantor dan banyak lagi. Tetapi material game yang dikirim tidak jauh dari materi sebelumnya ketika memegang kegiatan di udara terbuka. Trainee dengan mudah menyerap materi yang ditularkan oleh pembicara. Jadi bahan yang ditransmisikan akan lebih mudah diterapkan. Dari beberapa hasil wawancara, bahwa CV. XYZ, melakukan kegiatan pelatihan di awal tahun 2020 yang dilaksanakan di beberapa kota besar. Di mana kegiatan ini juga dilakukan selain membangun karakter individu, juga untuk membangun karakter tim atau juga disebutkan dengan Team Caracter Building.

\subsubsection{Sistem Penggajian}

Berikan gaji atau upah di sini sebagai timbal balik untuk pekerjaan ketenagakerjaan saat bekerja pada CV. XYZ. Berikan kompensasi dalam bentuk uang adalah hal yang paling penting untuk digunakan dalam organisasi untuk memotivasi kinerja karyawan. Karyawan dimotivasi oleh keinginan untuk menghasilkan uang. Kompensasi bukan satusatunya yang memotivasi karyawan. Namun, kompensasi adalah salah satu faktor utama yang mungkin mendorong seseorang untuk melakukan kegiatan atau pekerjaan lebih disukai. Di CV. XYZ ini sistem penggajian diberikan setiap akhir bulan, dimana gaji karyawan termasuk gaji UMR. Seperti yang telah di jelaskan oleh bagian personalia yang menyebutkan bahwa:

"Saya pikir kompensasi dalam bentuk uang, yang diberikan kepada karyawan CV. XYZ telah mengisi target upah minimum rakyat. Selain itu, juga untuk meningkatkan antusiasme karyawan, maka Gama memberikan kompensasi dalam bentuk lain dalam bentuk kegiatan di CV. XYZ mengadakan kegiatan wisata dengan atasan mereka. Dengan cara ini, setelah melakukan perjalanan bersama bersama sehingga kerjasama yang kuat di tim, itu juga akan menciptakan antusiasme untuk meningkatkan pencapaian masyarakat yang lebih baik."

Dari hasil wawancara di atas menjelaskan bahwa pentingnya pemberian kompensasi yang berupa uang ini sangat mempengaruhi semangat kerja karyawan. Dimana pemberian gaji ini menjadi timbal balik dari setiap kerja karyawan dalam perusahaan. Jika kebutuhan karyawan selesai, itu akan semakin mempercepat kemajuan kinerja karyawan di masyarakat. Selain itu, atasan harus melakukan kerjasama yang baik dengan karyawan mereka. Dengan demikian, tujuan perusahaan akan dicapai dengan kinerja yang baik.

\subsection{Pembahasan}

\subsubsection{Pelaksanaan Training}

Lebih dijelaskan, pengalaman belajar adalah konsep pelatihan di mana permainan (interior dan outdoor) digunakan untuk merangsang masalah yang terjadi setiap hari di masyarakat. Propelasi pembelajaran akan bekerja dengan sangat efektif jika para peserta bersedia berpartisipasi penuh. Dalam metode pembelajaran pengalaman, fasilitator tidak mengajarkan konsep, keterampilan atau nilai-nilai, tetapi memberi peserta kesempatan untuk memahami dan memahami konsep, keterampilan, atau nilai-nilai melalui pengalaman langsung. Konsep-konsep seperti kreativitas, komunikasi, kerja tim, 
kepemimpinan, dll. Beberapa faktor harus diberikan kepada karyawan dalam pelaksanaan kegiatan pelatihan, yaitu:

\section{a. Materi pelatihan}

Dari hasil wawancara, informan menyatakan bahwa materi yang diberikan kepada karyawan adalah yang paling penting. Karena, dengan menyediakan peralatan yang baik untuk peserta pelatihan, itu akan memungkinkan peserta untuk melatih dan memfasilitasi penangkapan peralatan yang disediakan. Materi yang disampaikan bersama pada psikologi individu karyawan, potensi pribadi dan sebagainya.

\section{b. Metode pelatihan}

Hasil wawancara, informan mengatakan bahwa meskipun banyak metode pelatihan, tetapi metode sering digunakan dan sesuai, yaitu metode expriential learning, yaitu proses pembelajaran pengalaman, karena ini. Metode lebih efisien sebagai sarana kesenangan untuk pelatihan pengalaman, Meningkatkan pengetahuan dan pengetahuan peserta dan dapat mendorong semangat karyawan untuk meningkatkan kinerja masyarakat.

\section{c. Kemampuan instruktur}

Di antara hasil wawancara, informan mengatakan menjadi instruktur yang andal, maka seorang instruktur harus menguasai materi untuk disampaikan kepada peserta pelatihan. Karena dengan kemampuan instruktur yang andal dan kontrol perangkat keras yang akan dikirim secara signifikan mempengaruhi jalannya kegiatan pelatihan. Sebagai instruktur harus memiliki kapasitas, yaitu, kemampuan teknis, keterampilan dan keterampilan dalam memahami lingkungan. Dan instruktur pelatihan yang ada dapat memberikan pemahaman atau benar-benar dapat mengirimkan materi kepada peserta.

\section{d. Fasilitas pelatihan}

Dari hasil wawancara, informan menyatakan bahwa fasilitas yang ada mampu mendukung kegiatan pelatihan, baik fasilitator kelompok dan fasilitator teknis (kamera, musik, dll.). Dan fasilitas yang ada, dapat memenuhi kebutuhan pelatihan sehingga dapat berfungsi dengan lancar. Selain itu, keamanan standar sebelum melakukan kegiatan pelatihan. Bermanfaat untuk menjaga peserta pelatihan dalam pelatihan.

\subsubsection{Kinerja Karyawan}

Setiap perusahaan menginginkan kemajuan dan kinerja karyawan yang baik. Kinerja baik karyawan juga harus didukung oleh benda kerja karyawan sendiri dan hubungan yang baik dengan atasan. Jadi, perusahaan dapat mencapai target yang diinginkan. Berikut hasil wawancara, yang dapat di lihat dari beberapa dimensi kinerja karyawan, antara lain:

\section{a. Tingkat Kemampuan dan keterampilan}

Hasil wawancara, informan menunjukkan bahwa setelah pelatihan, kapasitas dan keterampilan karyawan dapat dihitung. Karena kapasitas dan keterampilan memiliki karyawan, ia dapat membangun moral karyawan untuk kesuksesan yang lebih baik dan perasaan tanggung jawab yang tinggi dalam karyanya. Dan hasil penelitian ini menyatakan bahwa kapasitas karyawan belum lolos dari peran kegiatan pelatihan karyawan. Karyawan juga percaya bahwa ada perubahan setelah menyelesaikan pelatihan dan pengaruh pada kinerja karyawan Perusahaan. Kapasitas dan keterampilan termasuk, karyawan dapat menjadi kreatif dan inovatif, mencapai tujuan dan tujuan masyarakat.

\section{b. Tingkat Pengetahuan}

Dari hasil wawancara, para informan menyatakan bahwa pekerja yang dipekerjakan tidak akan berhasil jika tidak didukung oleh tingkat pengetahuan karyawan sendiri. Karena dalam hal ini, pengetahuan sangat penting dimiliki oleh karyawan untuk kegiatan 
Perusahaan. Karena, dengan pengetahuan, karyawan dapat meningkatkan keterampilan kreatif dan inovatif.

\section{c. Semangat kerja}

Hasil wawancara informan melaporkan bahwa pelatihan selain operasi sebagai pengembangan karyawan tetapi juga dapat mendorong semangat karyawan. Selain itu, kebutuhan untuk karyawan memiliki prestasi tinggi untuk mencapai kesuksesan kinerja. Jika pola ini ada dari karyawan Anda sendiri dan didukung oleh lingkungan kerja, akan lebih mudah bagi karyawan untuk melakukan kinerja. Akibatnya, semangat kerja sangat diperlukan untuk ada di antara karyawan dan dorongan para pemimpin sehingga tujuan perusahaan dapat dicapai. Intinya, kinerja karyawan akan meningkat dengan benda kerja yang kuat dari karyawan.

\section{d. Tingkat Kelancaran}

Di antara hasil wawancara, para informan menyatakan bahwa kelancaran implementasi tugas juga merupakan tanggung jawab masing-masing karyawan. Tetapi selain ini, itu juga membutuhkan dukungan positif bagi atasan. Pekerjaan lunak harus benar-benar diperhatikan karena jika kemahiran bekerja memiliki hambatan, ini akan mempengaruhi pekerjaan. Oleh karena itu, perlu untuk mengatur solusi dengan cepat. Dan hasil penelitian menyatakan bahwa karyawannya lancar dalam melaksanakan pekerjaan mereka. Itu semua dapat dilihat dari hasil wawancara sebelumnya.

Penjelasan data di atas bahwa untuk mengetahui bagaimana kinerja karyawan perusahaan, perlu untuk mengetahui dimensi kinerja antara kapasitas dan keterampilan karyawan, pengetahuan karyawan, semangat kerja dan bekerja dengan baik. Menjaga kinerja karyawan dengan baik, karyawan kemudian harus memiliki beberapa aspek, termasuk: rasa tanggung jawab atas pekerjaan yang dikonfirmasi, melakukan tujuan kerja dengan tepat dan sesuai dengan target, selalu memiliki hubungan baik dengan karyawan dengan memperkuat perasaan padat Kerjasama, memiliki keterampilan kapasitas yang dapat membuat perubahan pada setiap pekerjaan, benda kerja karyawan sehingga kinerja mencapai lebih mudah.

\subsubsection{Faktor Penghambat dalam Meningkatkan Kinerja Karyawan}

a. Tingkat pendidikan karyawan yang tergolong rendah, namun sebagian tingkat pendidikan karyawan antara Diploma sampai S1. Dengan rendahnya tingkat pendidikan karyawan akan memengaruhi pemahaman karyawan dari tujuan organisasi atau masyarakat, serta tugas dan kewajiban yang merupakan tanggung jawab.

b. Kurang tanggung jawab beberapa karyawan dalam pekerjaan mereka. Ini disebabkan oleh karyawan imperatif tentang fungsi dan kewajiban mereka. Umumnya ini terjadi pada karyawan baru.

c. Kurangnya kompak antara pekerja kerja yang diterjemahkan menjadi hubungan antara bagian pertama dan yang lain kurang harmonis. Sehingga dapat menyebabkan suasana yang tidak kondusif bagi lingkungan kerja.

\subsubsection{Faktor Pendukung Dalam Meningkatkan Kinerja Karyawan}

\section{a. Lingkungan}

Lingkungan kerja juga merupakan bagian penting dari bisnis. Lingkungan yang dekat dengan masyarakat dan tempat strategisnya akan memberikan kenyamanan kepada karyawan untuk mulai bekerja. Dengan lokasi strategis yang menawarkan suasana dan situasi kerja untuk kondusif. 


\section{b. Patner}

Di lingkungan bisnis perusahaan seperti keluarga dan bekerja dengan imbalan timbal balik ketika seorang karyawan dalam kesulitan, yang lain membantu tanpa menunggu kompensasi. Dengan bersama-sama, itu akan mudah dalam segala hal dan sebaliknya. Dengan demikian, karyawan akan memiliki rasa keluarga yang baik. Dan semua karyawan menghormati selera mereka untuk kecepatan mereka.

\section{c. Fasilitas}

Dalam lingkungan CV. XYZ fasilitas untuk mengembangkan diri sudah tersedia seperti ketika karyawan ingin mempraktekkan penemuan baru untuk memperoleh hasil yang maksimal dalam pekerjaannya. perusahaan memiliki alat dan area yang digunakan sebagai situs pelatihan. Selain itu, semua karyawan dipenuhi dengan kebutuhan seharihari, seperti sarapan, makan siang, makan malam telah disediakan. Karyawan tidak merasa kekurangan untuk memenuhi kebutuhan mereka setiap hari.

\subsubsection{Upaya yang Dilakukan untuk Mengatasi Faktor Penghambat dalam Meningkatkan Kinerja Karyawan}

Hambatan untuk implementasi kegiatan harus diselesaikan. Karena jika tidak ada upaya untuk mengatasinya, kendala ini akan menghambat peningkatan kinerja karyawan dan, pada akhirnya, tujuan perusahaan belum menyadari. Untuk mengatasi kendala di atas, maka perlu beberapa langkah-langkah yang harus dilakukan, antara lain:

a. Untuk meningkatkan pemahaman atau pemahaman karyawan dari tujuan korporasi dan kewajiban dan kewajibannya masing-masing, manajemen harus mengatur rapat rutin setidaknya sekali per bulan di mana para pemimpin, Direksi dan di semua karyawan. Ketika, dalam rapat, akan dibahas implementasi penugasan yang ditetapkan dan membahas masalah yang dapat terjadi dalam implementasi pekerjaan. Dan juga merencanakan Brefing kepada beberapa karyawan untuk meningkatkan kinerja karyawan.

b. Pengurusan terbuka, iaitu apabila pekerja mempunyai masalah pekerja, aduan atau aspirasi boleh menyalurkan dalam pelari.

c. Menyesuaikan tingkat kemampuan karyawan dengan beban pekerjaannya (the right man in the right place). Sehingga mereka dapat memahami dan melaksanakan fungsi mereka dengan benar.

d. Pertahankan pembinaan dan pengembangan sumber daya manusia. Di mana tahuntahun mendatang CV. XYZ akan merampas kalender kegiatan pelatihan karyawan dan praktik lapangan untuk menambah informasi dan pengetahuan.

e. Manajemen harus memperhatikan kesejahteraan karyawan. Mulai lembur, memberikan keuntungan bagi karyawan, seperti manfaat kesehatan, tunjangan liburan dan lainnya.

Seperti hasil wawancara dengan bagian personalia menjelaskan bahwa: "Kinerja meningkat setelah menemukan soul dan rasa persahabatan. Dan selain itu juga, dengan diterapkannya Outbound Training peserta juga akan mampu mengembangkan potensi diri, baik secara individu (Personal Development) maupun dalam kelompok (Team Development). Dan kinerja karyawan dapat dianggap sebagai kualitas dengan memeriksa dimensi kinerja tertentu, yaitu kapasitas dan keterampilan, tingkat pengetahuan, kerja lancar dan moral. Lalu CV. XYZ menyajikan karyawan yang memiliki kreativitas besar untuk menciptakan bentuk keberhasilan masyarakat yang baik. Memberikan dorongan agar karyawan tidak merasa jenuh dengan pekerjaan mereka. Oleh karena itu, saya bersama kru yang lain, menerapkan Outbound Training agar tercipta kerjasama yang baik 
antar karyawan dengan anggota yang lain. Dengan begitu, keharmonisan dalam bekerja akan tetap terjaga dengan baik. Ini untuk menambah dan mengembangkan pengetahuan tentang semua pengalaman. Karena mempelajari pengalaman kegiatan permainan digunakan sebagai sarana pembelajaran yang menyenangkan yang dapat dilakukan di ruang terbuka atau tertutup.

\section{Simpulan}

Sesuai dengan hasil penelitian yang diperoleh dan setelah di analisis, dapat disimpulkan beberapa poin penting. Pertama, pelatihan diterapkan pada CV. XYZ yaitu off the job training (outbound). Metode yang diterapkan adalah metode experiential learning (pengalaman belajar). Karena, dengan belajar dari pengalaman, itu digunakan sebagai alat yang menyenangkan, yaitu sarana untuk membentuk pengalaman, konsep diri sendiri, pemecahan masalah. Dan dapat menciptakan ketegangan, persahabatan dan menciptakan kerja sama yang solid antara peserta pelatihan. Kedua, dengan implementasi pelatihan, kinerja karyawan membaik. Hal ini dapat dilihat dari dimensi tertentu dari kinerja, yaitu kapasitas dan keterampilan karyawan, tingkat pengetahuan karyawan, moral karyawan dan kelancaran karyawan. Karyawan dapat membuat modifikasi, termasuk meningkatkan kinerja yang lebih baik. Karyawan menerima pelatihan untuk memiliki kepemimpinan yang kuat, berwibawa, yang bertanggung jawab, menciptakan antusiasme dalam kewirausahaan dan bagaimana menciptakan kinerja yang solid untuk kemajuan atau tujuan target perusahaan.

Ketiga, dengan implementasi outbound training, kinerja karyawan membaik. Hal ini dapat dilihat dari dimensi tertentu dari kinerja, yaitu kapasitas dan keterampilan karyawan, tingkat pengetahuan karyawan, moral karyawan dan kelancaran karyawan. Karyawan dapat membuat modifikasi, termasuk meningkatkan kinerja yang lebih baik. Karyawan menerima pelatihan untuk memiliki kepemimpinan yang kuat, berwibawa, yang bertanggung jawab, menciptakan antusiasme dalam kewirausahaan dan bagaimana menciptakan kinerja yang solid untuk kemajuan atau tujuan target perusahaan.

\section{Referensi}

Ancok, Djamaluddin, 2003. Outbound Manajemen Training (Aplikasi ilmu perilaku dalam pengembangan Sumber Daya Manusia). Cetakan Pertama. Edisi Revisi. Yogykarta: UII Pres.

Handoko, T. Hani. 2014. Manajemen Personalia Dan Manajemen Sumber Daya Manusia, Edisi Kedua. Yogyakarta: BPFE

Hasibuan, Malayu, 2002. Manajem Personalia dan Sumber Daya Manusia. Edisi Revisi. Jakarta: Bumi Aksara.

Hafidhuddin, Didin. 2003. Manajemen Syariah dalam Praktek. Jakarta: Gema Insani Press

Mangkunegara, Anwar Prabu, 2017. Evaluasi Kinerja Sumber Daya Manusia. Cetakan Pertama. Bandung: Refika Aditama

Martoyo, Susilo, 2010. Manajemen Sumberdaya Manusia. Edisi Empat. Yogyakarta: BPFE

Mathis Robert L dan Jackson, 2002. Manajemen Sumber Daya alih bahasa Sadeli dan Hie. Buku 2. Jakarta: Salemba Empat. 
Mangkuprawira, Sjafri. 2004. Manajemen Sumber Daya Manusia Strategik. Cetakan Ketiga. Jakarta: Penerbit Ghalia Indonesia

Ruky, Achmad S. 2006. Sistem Manajemen Kinerja. Cetakan Keempat. Jakarta: PT. Gramedia Pustaka Utama.

Schuler, Randal dan Sunan E. Jackson. 1997. Manajemen Sumber Daya Manusia abad 21 alih bahasa oleh Subari dan Yahya. Edisi ke-6 Jilid 1 Jakarta: Erlangga.

Sihotang. A. 2007. Manajemen Sumber Daya Manusia. Cetakan Pertama. Jakarta: PT. Pradnya Paramita.

Simamora, Henry. 2016. Manajemen Sumber Daya Manusia, Jakarta: Gramedia

Sugiyono. (2017). Metode Penelitian Kuantitatif, Kualitatif, dan R\&D. Bandung: Alfabeta.

Umar, Husein. 2013. Riset Sumber Daya Manusia dalam Organisasi. Jakarta: PT. Gramedia Pustaka Utama.

Teguh, Ambar S. R. 2003. Manajemen Sumber Daya Manusia. Edisi pertama. Yogyakarta: PT. Graha Ilmu. 